\title{
ANALISIS KEMAMPUAN KOGNITIF DAN KESULITAN BELAJAR SISWA PADA MATERI POKOK SISTEM PENCERNAAN MAKANAN DI KELAS XI IPA MAN DI KOTA MEDAN
}

\author{
Ummi Rapikah ${ }^{*}$, Tri Harsono, Darussalim, Herawati, Masdiana \\ ${ }^{1}$ Program Studi Pendidikan Biologi, FMIPA, Universitas Negeri Medan, \\ Jl. Willem Iskandar Psr. V Medan Estate, Medan, Indonesia, 20221 \\ *E-mail : Rapikahummi@gmail.com
}

\begin{abstract}
ABSTRAK
Penelitian ini bertujuan untuk Mengetahui tingkat kesulitan belajar siswa berdasarkan aspek kognitif pada materi pokok sistem pencernaan makanan kelas XI IPA MAN di kota Medan tahun pembelajaran 2016/2017. Faktor kesulitan belajar siswa diperoleh melalui angket dan tes yang divalidkan, siswa yang mengalami kesulitan belajar adalah siswa yang memiliki nilai dibawah KKM. Sampel dalam penelitian ini adalah 118 orang yang terdiri dari 48 Orang kelas XI Mia-6 MAN 1 Medan, 41 orang kelas XI IPA MAN 2 Model Medan dan 29 orang kelas XI Mia-5 MAN 3 Medan yang diambil secara cluter random dari sampel populasi. Berdasarkan analisis data secara deskriftif diperoleh tingkat kesulitan belajar siswa pada materi sistem pencernaan makanan dikelas XI IPA MAN di Kota Medan tahun pembelajaran 2016/2017 Tingkat kesulitan belajar siswa pada materi sistem pencernaan makanan di kelas XI IPA MAN di Kota Medan tahun pembelajaran 2016/2017 didapat persentase kesulitan belajar paling tinggi terdapat di Man 2 Model medan yaitu aspek C1, C2, C3 Termasuk kategori tinggi aspek C4 sedang dan aspek C5 masuk kategori sangat tinggi, sedangkan di Man 3 Medan aspek C1 tinggi sedanggkan aspek C2,C3,C4,C5 Termak dalam kategori rendah dan di Man 1 Medan masuk dalam kategori sedang.Berdasarkan data dari ketiga sekolah tersebut dapat dilihat bahwa di Man 3 Medan faktor internal sangat berpengaru sebagai penyebab kesulitan belajarsedangka pada faktor eksternal sanagat berpengaruh guru, media dan metode pembelajaran. Di Man 2 Model Medan faktor yang sangat berpengaruh hanya motivasi, lingkunga, media dan metode pembelajaran yang digunakan oleh guru. Dan Man 1 Medan hanya motivasi yang berpengaru sebagai penyebab kesulitan belajar siswa.
\end{abstract}

Kata Kunci : Kesulitan belajar

\section{ABSTRACT}

This study aims to determine the level of student learning difficulties based on cognitive aspects on the subject matter digestive system food grade XI IPA MAN in the city of Medan learning year 2016/2017. Students' learning difficulties were obtained through questionnaires and validated tests, students with learning difficulties were students who scored below the KKM. The sample in this research is 118 people consisting of 48 Orang class XI Mia-6 MAN 1 Medan, 41 class XI IPA MAN 2 Model Medan and 29 class XI Mia-5 MAN 3 Medan taken by cluter random from population sample. Based on data analysis descriptively obtained level of student's learning difficulties on food digestive system material class XI IPA MAN in Medan city of learning year 2016/2017 Degree of student's learning difficulties in material digestive system of food in class XI IPA MAN in Medan city year of study 2016/2017 obtained The highest percentage of learning difficulty is found in Man 2 Field model is C1, C2, C3 aspect Including high C4 aspect category and C5 aspect is very high category, while in Man 3 Medan C1 aspect is high as aspect C2, C3, C4, C5 Imperative In the category of low and in Man 1 Medan entered in the moderate category.Based on data from the three schools can be seen that in Man 3 Medan internal factors are very influential as the cause of difficulty learning in the external factors influencing teachers, media and learning methods. In Man 2 Medan Model factors that are very influential only motivation, environment, media and learning methods used by teachers. And Man 1 Medan is only the motivation of the newcomers as the cause of student learning difficulties.

Keywords: Learning difficulties 
JURNAL PELITA PENDIDIKAN VOL. 5 NO. 4

Rapikah, U., Harsono, T., Darussalim, Herawati, Masdiana

Halaman : 371 - 380

\section{PENDAHULUAN}

Pendidikan merupakan proses yang dilakukan secara sadar dan terencana untuk pembinaan perkembangan sumber daya manusia. Sedangkan perkembangan diartikan sebagai perubahan ke arah yang positif atau lebih baik. Dengan melaksanakan pendidikan, manusia akan menjadikan dirinya lebih berkualitas. Pendidikan telah memberikan banyak kontribusi terhadap perkembangan pengetahuan dan teknologi. Dengan pengetahuan dan perkembangan teknologi manusia dapat menyelesaikan permasalahan yang timbul untuk memenuhi kebutuhan manusia. Oleh sebab itu pendidikan memiliki peran yang penting bagi kehidupan manusia. Manusia dituntut untuk tetap meningkatkan kualitas sumber daya manusia dan mutu pendidikan (Friska, 2015) .

Kesulitan belajar merupakan suatu gangguan dalam satu atau lebih proses psikologis yang mencakup pemahaman dan penggunaan bahasa ujaran atau tulisan. Gangguan tersebut mungkin menampakkan diri dalam bentuk kesulitan mendengarkan, berpikir, berbicara, membaca, menulis, mengeja atau berhitung. Batasan tersebut mencakup kondisi-kondisi seperti gangguan perseptual, luka pada otak, disleksia, dan afasia perkembangan. Batasan tersebut tidak mencakup anak-anak yang memiliki problema belajar yang penyebab utamanya berasal dari adanya hambatan dalam penglihatan, pendengaran, atau motorik, hambatan karena tunagrahita, karena gangguan emosional, atau karena kemiskinan lingkungan, budaya, atau ekonomi.

Kesulitan belajar sering dialami siswa dalam bidang studi biologi. Hal ini disebabkan materi biologi sifatnya eksakta yang memerlukan pemahaman dan penerapan serta biologi merupakan ilmu pengetahuan yang berusaha untuk mengungkapkan materi-materi yang menyangkut mahkluk hidup dan lingkungan maka siswa terkadang mengalami kesulitan dalam menguasai pelajaran tersebut. Berdasarkan data penelitian Siregar (2012), faktor dominan penyebab kesulitan belajar siswa pada pelajaran biologi adalah faktor psikologi, faktor keluarga, dan faktor biologis. Tingkat kesulitan belajar yang dialami oleh siswa
pISSN : 2338 - 3003

elSSN : 2502 - 3217

adalah 56,21\% yang berarti cukup menghambat proses pembelajaran biologi, yang mana penjabarannya adalah : Psikiatrik (67,03 \%), Inteligensi $(58,33 \%)$, Minat $(59,25)$, Motivasi ( 59,58\%), Orang tua $(36,87)$, guru 50,12\%, lingkungan sekolah $(38,33 \%)$, psikiatrik $(60,46 \%)$, media $(52,87 \%)$, biologis $(80,20 \%)$.

Penelitian ini dilakukan di MAN yang ada di kota medan karena dari hasil observasi dan pengalaman PPLT didapat bahwa sebagian siswa berpendapat bahwa pelajaran biologi itu merupakan pelajaran yang membosankan, banyak hapalan, dan menggunakan bahasa latin yang susah di ucapkan dan di ingat. Hal ini dapat di seabkan oleh faktor dari dalam diri sendiri siswa tersebut, seperti kurangnya minat belajar siswa dalam pelajaran biologi, faktor sekolah juga berpengaruh, seperti penggunaan model dan metode pembelajaran yang kurang bervasiasi dan efektif, kurang dimanfaatkannya fasilitas sekolah yang ada seperti laboratorium dan perpustakaan, dan juga dapat dipengaruhi oleh faktor keluarga, seperti bimbingan keluarga yang kurang terhadap belajar biologi anak dan kurangnya motivasi dari keluarga.

Penelitian ini juga dilatar belakangi oleh rendahnya hasil belajar siswa pada materi sistem pencernaan makanan di kelas XI IPA MAN yang ada di kota Medan. Dari hasil wawancara dengan salah seorang guru biologi di MAN 2 Model Medan ibu Dra. $\mathrm{Hj}$. Ida Iriani, M.Pd diperoleh bahwa hasil belajar siswa pada materi sistem pencernaan makan masih termasuk kategori rendah, dan terlihat dari hasil belajar siswa yang dibawah KKM yaitu dibawah 85. Selain itu berdasarkan hasil wawancara dengan guru biologi Man 1 Medan bahawa masih banyak siswa yang nilainya di bawah KKM yaitu dibawah 83 . Begitu juga dengan siswa di MAN 3 Medan banyak siswa yang nilainya di bawah KKM yaitu 80

Untuk memahami sebarapa besar tingkat kemampuan kognitif dan kesulitan belajar siswa, maka dapat dilakukan dengan berbagai cara, salah satunya dengan menganalisis hasil evaluasi belajar siswa. Setelah diketahui kesulitan yang dihadapi siswa dan seberapa besar tingkat kemampuan kognitif dan kesulitannya, maka dapat dilakukan perbaikan untuk mengatasi permasalahan tersebut, dari hasil analisis 
tersebut juga akan diketahui faktor penyebab kesulitan belajar .

\section{METODE PENELITIAN}

Penelitian ini dilaksanakan di MAN yang ada di kota Medan, yaitu: (a) di MAN 1 Medan, Jl. Willem Iskandar No. 7B. Medan, (b) Di MAN 2 Model Medan, Jl. Willem Iskandar No. 7A, Medan, (c) Di MAN 3 Medan, Jl. Pertahanan Patumbak. Penelitian yang dilakukan merupakan penelitian deskriptif, yaitu untuk menganalisis kesulitan belajar serta faktor-faktor yang mempengaruhi kesulitan belajar siswa. Jenis Penelitian ini menggunaka data kuantitatif yang merupakan nilai dari hasil belajar siswa dan angket yang diberikan penskoran.. Pengambilan sampel dalam penelitian ini adalah dengan cara random sampling. Sampel dalam penelitian ini berjumlah 118 siswa, yaitu kelas XI MIA 6 berjumlah 46 orang di MAN 1 Medan. Kelas XI IPA 6 yang berjumlah 40 orang di MAN 2 Model Medan. Kelas XI MIA 5 yang berjumlah 32 orang di MAN 3 Medan.Untuk memperoleh data yang dibutuhkan, maka instrumen yang digunakan dalam penelitian ini ada dua jenis, yaitu tes dan angket.
Tes hasil belajar pada maateri sistem pencernaan makanan disusun dalam bentuk pilihan ganda sebanyak 25 soal dan terdiri dari 5 (lima) pilihan jawaban yang telah divalidasi. Soal disusun berdasarkan indikator dari silabus guru biologi . Tes diberikan setelah pembelajaran materi sistem pencernaan makanan selesai. Kaidah penskoran pada tes hasil belajar ini yaitu, siswa yang nilai hasil tesnya memenuhi ( $\geq 70$ ) tidak diikutsertakan dalam pengisian angket, sedangkan siswa yang nilai hasil tesnya di bawah $(<70)$ diikutsertakan pengisian angket.

\section{ANGKET}

Angket yang digunakan adalah angket tertutup yang terdiri dari 35 pernyataan. Masing-masing pernyataan disediakan pilihan yang menjadi alternatif jawaban dan perhitungan skor menggunakan skala linkert dengan ketentuan: (1) untuk pernyataan dengan kriteria positif: 1=tidak pernah, 2=kadangkadang $3=$ sering, $4=$ selalu. (2) untuk pernyataan dengan kriteria negatif: $1=$ selalu, $2=$ sering, $3=$ kadangkadang, 4=tidak pernah.

Tabel 1. Kisi-Kisi Angket Analisis Faktor Kesulitan Belajar Siswa

\begin{tabular}{|c|c|c|}
\hline $\begin{array}{c}\text { Aspek yang } \\
\text { diamati }\end{array}$ & Deskriptor & $\begin{array}{c}\text { Jumlah } \\
\text { Item }\end{array}$ \\
\hline Kesehatan & $\begin{array}{l}\text { siswa tidak dapat melihat dengan jelas tulisan pada saat belajar materi sistem pencernaan } \\
\text { makanan } \\
\text { siswa tidak dapat mendengarkan suara guru dengan jelas pada saat belajar materi sistem } \\
\text { pencernaan makanan } \\
\text { siswa suka mengantuk saat pelajaran sistem pencernaan makanan }\end{array}$ & 3 \\
\hline Minat & $\begin{array}{l}\text { Siswa memahami materi sistem pencernaan } \\
\text { Siswa tidak menyukai materi sistem pencernaan makanan } \\
\text { Siswa tidak mempersiapkan mempersiapkan diri di rumah sebelum mempelajari materi } \\
\text { sistem pencernaan makanan } \\
\text { Siswa tidak pernah mengulang materi sistem pencernaan makanan sebelum ujian }\end{array}$ & 4 \\
\hline Motivasi & $\begin{array}{l}\text { Siswa merasa tidak berguna mempelajari mempelajari materi sistem pencernaan makan } \\
\text { Siswa mencari sendiri jawaban pertanyaan } \\
\text { Siswa merasa sistem pencernaan makanan tidak mendukung pencapaina cita-citanya } \\
\text { Siswa tidak tertarik tertarik mempelajari lebih dalam tentang sistem pencernaan makanan. }\end{array}$ & 4 \\
\hline Psikiatis & $\begin{array}{l}\text { Siswa tidak konsentrasi dalam mengikuti pelajaran sistem pencernaan makanan. } \\
\text { Siswa suka menyendiri atau melamun saat pembelajaran } \\
\text { Siswa suka mengganggu teman saat belajar sistem pencernaan makanan. }\end{array}$ & 3 \\
\hline Lingkungan & $\begin{array}{l}\text { Orangtua tidak mendukung atau membimbing siswa untuk belajar. } \\
\text { Orang tua tidak pernah menyediakan bimbingan belajar/les } \\
\text { Kakak/abang membantu belajar sistem pencernaan di rumah }\end{array}$ & 3 \\
\hline
\end{tabular}




\begin{tabular}{ll}
\hline Sekolah & Waktu yang digunakan dalam mempelajari materi sistem pencernaan makanan sangat \\
& sedikit. \\
& Siswa tidak nyaman belajar didalam kelas. \\
& Fasilitas sekolah mendukung pembelajaran \\
& Laboratorium di sekolah tidak mendukung pembelajaran tentang sistem pencernaan \\
& makanan. \\
& Siswa tidak pernah memanfaatkan perpustakaan sekolah saat mempelajari materi sistem \\
& pencernaan makanan. \\
\hline Guru & Guru biologi tidak bersikap demokratis saat mengajar. \\
& Guru biologi tidak berpenampilan menarik saat mengajar. \\
\hline Materi & Siswa tidak mengerti istilah-istilah yang digunakan dalam materi sistem pencernaan \\
& makanan. \\
& Siswa kesulitan dalam memberi nama bagian-bagian sistem pencernaan manusia (nama \\
& latin). \\
& Siswa kesulitan dalam mengumpulkan informasi tentang teknologi yang mungkin untuk \\
& membantu kelainan pada sistem pencernaan. \\
\hline Media & Siswa memiliki banyak kegiatan di luar sekolah. \\
& Siswa sering menghabiskan waktu menonton televisi. \\
& Siswa sering menghabiskan waktu untuk memainkan HP-nya. \\
\hline Metode/ & Guru sering menggunakan metode ceramah saat mengajar. \\
strategi & Guru tidak pernah memvariasikan metode/strategi belajar. \\
belajar & Siswa sulit mengikuti metode yang digunakan guru \\
& Siswa sulit memahami strategi pembelajaran yang dilakukan oleh guru. \\
& Siswa kesulitan menyimpulkan pelajaran di akhir pembelajaran \\
\hline & \multicolumn{1}{c}{ Jumlah seluruhnya } \\
\hline
\end{tabular}

Untuk memperoleh data yang dibutuhkan, maka alat pengumpulan data yang digunakan adalah uji validasi, uji reliabilitas, taraf kesukaran soal, dan daya beda soal (Arikunto, 2013). Analisis data dalam penelitian ini menggunakan metode deskriptif kuantitatif. Secara deskriptif dimaksudkan untuk memberikan jawaban terhadap rumusan masalah yaitu mengenai kesulitan belajar pada materi Sistem Ekskresi Manusia. Dari hasil belajar siswa ditentukan ketuntasan belajar siswa individual dipakai rumus :

$$
\text { Ketuntasan Belajar }=\frac{\text { Skor yang diperoleh siswa }}{\text { Skor maksimal }} \times 100 \%
$$

Menghitung persentase siswa yang mengalami kesulitan untuk tiap indikator soal dan membuat tabel yang berisi persentase siswa yang mengalami

$$
\% \text { Kesulitan }=\frac{\text { Jumlah siswa menjawab salah pada tiap indikator }}{\text { Jumlah seluruh siswa }} \times 100 \%
$$

Berdasarkan uraian di atas dapat disusun kriteria kesulitan siswa menurut Arikunto (2013):

Kesalahan siswa $0-10 \% \quad$ : kesulitan sangat rendah

Kesalahan siswa 11-20\% : kesulitan rendah

Kesalahan siswa $21-35 \% \quad$ : kesulitan sedang

Kesalahan siswa $36-45 \%$ : kesulitan tinggi

Kesalahan siswa $46-100 \%$ : kesulitan sangat tinggi

Hasil angket dianalisis dengan cara mencari rata-rata skor angket siswa, jumlah total skor yang dicapai pada tiap indikator angket dengan rumus: 
Skor indikator $=\frac{\text { jumlah skor angket siswa }}{\text { jumlah siswa }}$

Setelah itu, mencari kategori hasil angket yang diperoleh oleh siswa dengan rumus:

Indikator:

$(\mathrm{T})=85 \%$ skor maksimal tiap siswa

$(S)=75 \%$ skor maksimal tiap siswa

$(R)=61 \%$ skor maksimal tiap siswa

\section{HASIL PENELITIAN}

Hasil tes diagnostik menunjukkan dari bahwa dari 48 orang siswa yang mengerjakan tes di Man 1 Meda , 27 siswa tuntas dan 21 orang iswa tidak tuntas artinya $43,75 \%$ siswa yang tidak dapat mencapai tingkat penguasaan $65 \%$ pada materi sistem pencernaan makanan. Di Man 2 Model medandari 42 siswa yang mengerjakan tes 11 orang siswa tuntas dan 31 siswa tidak tuntas artinya 73,80 \% siswa tidak mencapai tingkat penguasaan $65 \%$ pada materi sistem pencernaan makanan. Di Man 3 Medan dari 29 siswa yang mengerjakan tes terdapat 26 siswa tuntas dan 3 siswa tidak tuntas artinya hanya $10,3 \%$ siswa tidak mencapai penguasaan $65 \%$ pada materi sistem pencernaan makanan. Sifat dan nilai rata-rata yang didapat adalah di Man 1 Medan sebesar 29 (60,4\%) artinya tidak tuntas karena didalam kelas tersebut tidak mencapai ketuntasan 85\%. Di man 2 Model Medan nilai rata-rata kelas yang diperoleh sebesar 25 (59.52\%) ketuntasan kelasnya dan dinyatakan tidak tuntas . di Man 3 Medan diperoleh nilai rata-rata kelas sebesar 21,6 (74,4\%) dan masuk dalam kategori tidak tuntas juga. Hal ini menunjukkan siswa kelas XI IPA MAN Di Kota Medan mengalami kesulitan dalam belajar pada materi sistem pencernaan makanan pada tahun pembelajaran 2016/2017 dan kesulitan tertinggi terdapat di Man 2 Model Medan. Berdasarkan perolehan skor tes diagnostik dapat diketahui bahwa siswa mengalami kesulitan belajar pada materi sistem pencernaan makanan, hal ini terlihat dari rendahnya presentase penguasaan siswa pada materi ini sehingga dilakukan analisis kesulitan belajar siswa pada aspek kognitif.

Di MAN 1 Medan pada aspek kognitif, presentase kesulitan belajar siswa pada tingkat pengetahuan (C1) yaitu sebesar 43,41\%, yang dimasukkan ke dalam kategori tinggi, presentase kesulitan belajar pada tingkat pemahaman (C2) yaitu sebesar 37, 13\%, yang masuk ke dalam kategori tinggi, pada tinggkat penerapan (C3) sebesar 39,6\%, yang masuk ke dalam kategori tinggi, tingkat analisis (C4) sebesar 31,25\% yang masuk ke dalam kategori sedang, pada tingkat sintesis (C5) sebesar 47,92\%, yang masuk ke dalam kategori sangat tinggi. Di Man 2 Model Medan aspek pengetahuan (C1) yaitu sebesar 45,53\%, yang dimasukkan ke dalam kategori tinggi, presentase kesulitan belajar pada tingkat pemahaman (C2) yaitu sebesar 36,59\%, yang masuk ke dalam kategori tinggi, pada tinggkat penerapan (C3) sebesar 44,52\%, yang masuk ke dalam kategori tinggi, tingkat analisis (C4) sebesar 30,9\% yang masuk ke dalam kategori sedang, pada tingkat sintesis (C5) sebesar $48,79 \%$, yang masuk ke dalam kategori sangat tinggi. Di Man 3 Medan aspek pengetahuan (C1) yaitu sebesar 41,96\%, yang dimasukkan ke dalam kategori tinggi, presentase kesulitan belajar pada tingkat pemahaman (C2) yaitu sebesar 12,65\%, yang masuk ke dalam kategori rendah, pada tinggkat penerapan (C3) sebesar $19,83 \%$, yang masuk ke dalam kategori rendah, tingkat analisis (C4) sebesar 16,1\% yang masuk ke dalam kategori sedang, pada tingkat sintesis (C5) sebesar $18,97 \%$, yang masuk ke dalam kategori rendah.

Setelah diketahui data tiap indikator maka skor tersebut akan disesuaikan dengan kategori tinggi, sedang, atau rendah. Artinya akan diketahui skor angket tersebut sangat berpengaruh, berpengaruh atau kurang berpngaruh dalam penyebab faktor kesulitan belajar siswa pada materi sistem pencernaan makanan. Hasil pada tabel 4.3 merupakan kategori tingkat kesulitan belajar siswa di kelas XI IPA Man 1 Medan, dimana faktor yang paling berpengaruh sebagai penyebab kesulitan belajar adalah indikator motivasi. 
Tabel 1. Kategori Tingkat Kesulitan Belajar Siswa

\begin{tabular}{ccccccc}
\hline \multirow{2}{*}{$\begin{array}{c}\text { No } \\
\text { Item }\end{array}$} & Indikator & Hasil & \multicolumn{3}{c}{ Skor } & Kategori dukungan \\
\cline { 4 - 5 } & & Angket & Tinggi & Sedang & Rendah & Kesulitan belajar \\
\hline 1 & Kesehatan & 2,01 & 3,4 & 3 & 2,44 & Kurang berpengaruh \\
2 & Minat & 3,03 & 3,4 & 3 & 2,44 & Berpengaruh \\
3 & Motivasi & 3,63 & 3,4 & 3 & 2,44 & Sangat berpengaruh \\
4 & Psikologi & 2,98 & 3,4 & 3 & 2,44 & Kurang berpengaruh \\
5 & Lingkungan & 2,31 & 3,4 & 3 & 2,44 & Kurang berpengaruh \\
6 & Sekolah & 2,15 & 3,4 & 3 & 2,44 & Kurang berpengaruh \\
7 & Guru & 2,85 & 3,4 & 3 & 2,44 & Kurang berpengaruh \\
8 & Materi & 2,75 & 3,4 & 3 & 2,44 & Kurang berpengaruh \\
9 & Media & 3,08 & 3,4 & 3 & 2,44 & \\
10 & Metode & 2,84 & 3,4 & 3 & 2,44 & Kerpengaruh \\
\hline
\end{tabular}

Tabel. 2. Kategori Tingkat Kesulitan Belajar Siswa MAN 2 Model Medan

\begin{tabular}{ccccccc}
\hline \multirow{2}{*}{$\begin{array}{c}\text { No } \\
\text { Item }\end{array}$} & Indikator & Hasil & \multicolumn{3}{c}{ Skor } & Kategori dukungan \\
\cline { 3 - 5 } & & Angket & Tinggi & Sedang & Rendah & Kesulitan belajar \\
\hline 1 & Kesehatan & 2,28 & 3,4 & 3 & 2,44 & Kurang berpengaruh \\
2 & Minat & 3,17 & 3,4 & 3 & 2,44 & Berpengaruh \\
3 & Motivasi & 3,85 & 3,4 & 3 & 2,44 & Sangat berpengaruh \\
4 & Psikologi & 3,2 & 3,4 & 3 & 2,44 & Berpengaruh \\
5 & Lingkungan & 4,5 & 3,4 & 3 & 2,44 & Sangat berpengaruh \\
6 & Sekolah & 2,75 & 3,4 & 3 & 2,44 & Kurang berpengaruh \\
7 & Guru & 2,85 & 3,4 & 3 & 2,44 & Kurang berpengaruh \\
8 & Materi & 3,3 & 3,4 & 3 & 2,44 & Berpengaruh \\
9 & Media & 3,73 & 3,4 & 3 & 2,44 & Sangat berpengaruh \\
10 & Metode & 3,9 & 3,4 & 3 & 2,44 & Sangat berpengaruh \\
\hline
\end{tabular}

Tabel 3. Kategori Tingkat Kesulitan Belajar Siswa MAN 3 Medan

\begin{tabular}{|c|c|c|c|c|c|c|}
\hline \multirow{2}{*}{$\begin{array}{l}\text { No } \\
\text { Item }\end{array}$} & \multirow[t]{2}{*}{ Indikator } & \multirow{2}{*}{$\begin{array}{c}\text { Hasil } \\
\text { Angket }\end{array}$} & \multicolumn{3}{|c|}{ Skor } & \multirow{2}{*}{$\begin{array}{l}\text { Kategori dukungan } \\
\text { Kesulitan belajar }\end{array}$} \\
\hline & & & Tinggi & Sedang & Rendah & \\
\hline 1 & Kesehatan & 2,16 & 3,4 & 3 & 2,44 & Kurang berpengaruh \\
\hline 2 & Minat & 3,45 & 3,4 & 3 & 2,44 & Sangat Berpengaruh \\
\hline 3 & Motivasi & 4,14 & 3,4 & 3 & 2,44 & Sangat berpengaruh \\
\hline 4 & Psikologi & 3,4 & 3,4 & 3 & 2,44 & Sangat Berpengaruh \\
\hline 5 & Lingkungan & 2,83 & 3,4 & 3 & 2,44 & Kurang berpengaruh \\
\hline 6 & Sekolah & 3,06 & 3,4 & 3 & 2,44 & Berpengaruh \\
\hline 7 & Guru & 3,6 & 3,4 & 3 & 2,44 & Sangat berpengaruh \\
\hline 8 & Materi & 3,22 & 3,4 & 3 & 2,44 & Berpengaruh \\
\hline 9 & Media & 4,02 & 3,4 & 3 & 2,44 & Sangat berpengaruh \\
\hline 10 & Metode & 4,02 & 3,4 & 3 & 2,44 & Sangat berpengaruh \\
\hline
\end{tabular}

Berdasarkan data dari ketiga sekolah tersebut dapat dilihat bahwa di Man 3 Medan faktor internal sangat berpengaru sebagai penyebab kesulitan belajarsedangka pada faktor eksternal sanagat berpengaruh guru, media dan metode pembelajaran.
Di Man 2 Model Medan faktor yang sangat berpengaruh hanya motivasi, lingkunga, media dan metode pembelajaran yang digunakan oleh guru. Dan Man 1 Medan hanya motivasi yang berpengaru sebagai penyebab kesulitan belajar siswa. 
JURNAL PELITA PENDIDIKAN VOL. 5 NO. 4

Rapikah, U., Harsono, T., Darussalim, Herawati, Masdiana

Halaman : 371 - 380

Dari hasil penelitian diperoleh mengenai letak kesulitan belajar siswa pada materi sistem pencernaan makanan berdasarkan aspek kognitif di kelas XI IPA MAN di Kota Medan Tahun Pembelajaran 2016/2017. Letak kesulitan belajar siswa berdasarkan aspek kognitif dideskripsikan sebagai berikut:

Di Man 1 Medan pada aspek kognitif, presentase kesulitan belajar siswa pada tingkat pengetahuan (C1) yaitu sebesar 43,41\%, yang dimasukkan ke dalam kategori tinggi, presentase kesulitan belajar pada tingkat pemahaman (C2) yaitu sebesar 37, 13\%, yang masuk ke dalam kategori tinggi, pada tinggkat penerapan (C3) sebesar 39,6\%, yang masuk ke dalam kategori tinggi, tingkat analisis (C4) sebesar 31,25\% yang masuk ke dalam kategori sedang, pada tingkat sintesis (C5) sebesar 47,92\%, yang masuk ke dalam kategori sangat tinggi. Di Man 2 Model Medan aspek pengetahuan (C1) yaitu sebesar $45,53 \%$, yang dimasukkan ke dalam kategori tinggi, presentase kesulitan belajar pada tingkat pemahaman (C2) yaitu sebesar $36,59 \%$, yang masuk ke dalam kategori tinggi, pada tinggkat penerapan (C3) sebesar $44,52 \%$, yang masuk ke dalam kategori tinggi, tingkat analisis (C4) sebesar 30,9\% yang masuk ke dalam kategori sedang, pada tingkat sintesis (C5) sebesar $48,79 \%$, yang masuk ke dalam kategori sangat tinggi. Di Man 3 Medan aspek pengetahuan (C1) yaitu sebesar $41,96 \%$, yang dimasukkan ke dalam kategori tinggi, presentase kesulitan belajar pada tingkat pemahaman (C2) yaitu sebesar $12,65 \%$, yang masuk ke dalam kategori rendah, pada tinggkat penerapan (C3) sebesar $19,83 \%$, yang masuk ke dalam kategori rendah, tingkat analisis (C4) sebesar $16,1 \%$ yang masuk ke dalam kategori sedang, pada tingkat sintesis (C5) sebesar $18,97 \%$, yang masuk ke dalam kategori rendah.

Dari data tiga sekolah tersebut didapat persentase kesulitan belajar paling tinggi terdapat di Man 2 Model medan yaitu aspek C1, C2, C3 Termasuk kategori tinggi aspek C4 sedang dan aspek C5 masuk kategori sangat tinggi, sedangkan di Man 3 Medan aspek C1 tinggi sedanggkan aspek C2,C3,C4,C5 Termak dalam kategori rendah dan di Man 1 Medan masuk dalam kategori sedang.
pISSN : 2338 - 3003

elSSN : 2502 - 3217
Berdasarkan hasil penelitian di atas dapat diketahui bahwa siswa kelas XI IPA MAN Di Kota Medan mengalami kesulitan belajar pada materi sistem pencernaan makanan. Terdapat banyak faktor yang menyebabkan siswa mengalami kesulitan belajar, faktor kesulitan tersebut dapat dikelompokkan menjadi faktor internal dan faktor eksternal. Faktor internal berasal dari dalam diri siswa sedangkan faktor eksternal berasal dari luar diri siswa atau lingkungan. Faktor internal terdiri dari kesehatan, minat motivasi dan psikologis sedang faktor eksternal terdiri dari lingkungan, sekolah, guru, materi pembelajaran, media, dan metode pembelajaran yang digunakan oleh guru.

\section{Faktor Kesehatan}

Dari hasil penskoran angket hasilnya menujukkan bahwa siswa memiliki kesehatan yang baik dalam hal kesehatan, pada pengelihatan siswa mampu melihat materi pelajaran yang di tulis guru di papan tulis serta mampu mendengar suara guru saat menjelaskan pelajaran, akan tetapi siswa terkadang suka mengantuk pada saat pembelajaran materi sistem pencernaan makanan berarti kondisi fisik siswa kurang baik dalam menerima pelajaran.

Dengan kemampuan fisik yang kurang maka akan mempengaruhi gaya belajar peserta didik tersebut. Pada peserta didik yang memiliki gaya belajar visual biasanya lebih mudah menyerap dan memproses informasi degan melihat atau mesnggunakan mata, dalam hal penglihatan ada sebagian kecil siswa yang tidak dapat melihat tulisan guru di depan akan tetapi kebanyakan siswa masih dapat melihat, jadi di simpulkan bahwa faktor kesehatan merupakan faktor yang kurang mempengaruhi kesulitan belajar siswa (Fauzi, 2012).

\section{Faktor Minat}

Faktor minat kurang mendukung terhadap faktor kesulitan belajar siswa karena banyak siswa yang kurang mudah memahami pelajaran sistem pencernaan yang di ajarkan oleh guru, dan bahkan siswa tidak pernah mempersiapkan diri di rumah sebelum belajar di sekolah, kemudian siswa tidak mengulang pelajaran di rumah, akan tetapi 
JURNAL PELITA PENDIDIKAN VOL. 5 NO. 4

Rapikah, U., Harsono, T., Darussalim, Herawati, Masdiana

Halaman : 371 - 380

kebanyakan siswa menyukai materi sistem pencernaan makanan.

Lebih lanjut dijelaskan minat adalah suatu rasa suka dan ketertarikan pada suatu hal atau aktivitas, tanpa ada yang menyuruh, seseorang yang memiliki minat terhadap suatu kegiatan tertentu cendrung memberikan perhatian yang besar terhadap kegiatan tersebut. Tentunya dalam melaksanakan kegiatan dan usaha pencapaian tujuan perlu adanya pendorong untuk menumbuhkan minat yang dilakukan oleh guru, semangat pendidik dalam mengajar siswa berhubungan erat dengan dengan minat siswa yang belajar. (Fauzi, 2012).

\section{Faktor Motivasi}

Faktor motivasi, faktor ini kurang mendukung dalam penyebab kesulitan belajar siswa, siswa merasa motivasi siswa cukup baik untuk mempelajari sistem pencernaan makanan, karena siswa merasa materi sistem pencernaan makanan berguna untuk dipelajari, dan mendukung pencapaian cita-cita siswa, dan sebagian siswa tertarik mempelajari lebih dalam lagi materi sistem pencernaan makan, akan tetapi siswa mencari jawaban dari pertanyaan sistem pencernaan makanan yang susah mereka hanya kadang- kadang mencarinya sendiri.

Pemberian motivasi yang tepat pada peserta didik akan mendukung semangat belajarnya dan memberikan dorongan pada peserta didik untuk mencapai prestasi yang optimal. Guru dapat menumbuhkan motivasi belajar siswa dengan berbagai cara, salah satu yang dilakukan adalah dengan memberikan reward kepada siswa yang dapat meraih prestasi yang tinggi. Dengan demikian siswa yang lain akan termotivasi untuk lebih giat lagi belajar untuk meraih prestasi yang lebih baik lagi. Motivasi belajar yang kuat dalam diri peserta didik akan mendorong peserta didik lebih semangat dalam belajar dan meraih prestasi belajar yang optimal (Fauzi, 2012).

Hasil penelitian menunjukkan motivasi belajar siswa rendah. Hasil penelitian ini sejalan dengan hasil penelitian Syeku (2009) dan juga Untari (2011) bahwa terdapat pengaruh positif dan signifikan antara motivasi dan prestasi belajar.
pISSN : 2338 - 3003

elSSN : 2502 - 3217

\section{Faktor Psikologi}

Faktor psikologis, faktor ini mendukung dalam hal menyebabkan kesulitan belajar siswa pada materi sistem pencernaan makanan, dari data yang diperoleh siswa kurang merespon pelajaran yang diberikan oleh guru. Sebagian siswa kurang konsentrasi saat mengikuti pelajran sistem pencernaan makanan, dan sebagian siswa ada yang suka menyendiri saat pelajaran sistem pencernaan berlangsung. Dalam hal ini siswa kurang kesiapan dari segi psikologis dalam mendukung pembelajaran sistem pencernaan makanan.

Faktor psikologis merupakan faktor yang berhubungan dengan rohaniyah, faktor psikologis dapat mempengaruhi belajar siswa antara lain intelegensi, minat, bakat dan motivasi. Siswa yang memiliki tingkat intelegensi yang tinggi akan lebih berhasil dalam belajar dari pada siswa yang memiliki tingkat intelegensi yang rendah. Minat dan motivasi juga besar peranannya dalam menentukan keberhasilan seseorang dalam belajar. Dengan demikian faktor internal ini yang berkaitan dengan jasmani perlu dijaga dan dibina serta dilatih untuk terbiasa melakukan sesuatu yang berkaitan dengan belajar. Konsep belajar akan lebih mudah bila kondisi fisik dalam keadaan sehat (Fauzi, 2012).

\section{Faktor Eksternal Lingkungan}

Faktor lingkunga, faktor ini kurang mendukung penyebab kesulitan belajar siswa. Dilihat dari orang tua selalu mendukung anaknya dalam belajar, dan orang tua siswa pun kebanyakan menyiapkan bimbingan belajar (les privat) untuk mendukung pelajaran anaknya.

Pendidikan berlangsung dimanapun, kapan pun, dan oleh siapa pun. Sehingga pendidikan tanggung jawab bersama. Menurut slameto bahwa orang tua yang kurang atau tidak memperhatikan kepentingan dan kebutuhan-kebutuhan anaknya dalam belajar dapat menjadikan anak malas dalam belajar dan menyebabkan anak kurang berhasil dalam belajarnya. Perhatian orang tua dapat dilakukan dengan cara memberi penghargaan, menyediakan fasilitas belajar dan membantu kegiatan belajar anak (Slameto. 2010). 
JURNAL PELITA PENDIDIKAN VOL. 5 NO. 4

Rapikah, U., Harsono, T., Darussalim, Herawati, Masdiana

Halaman : 371 - 380

\section{Sekolah}

Faktor sekolah, faktor ini kurang mendukung terhadap penyebab kesulitan belajar siswa, dilihat fasilitas yang ada di sekolah sudah mendukung pembelajaran siswa, dan siswa pun sudah memanfaatkan fasilitas tersebut dengan baik, akan tetapi siswa jarang sekali melakukan praktikum dan memanfaatkan laboratorium yang ada. Mengemukakan bahwa yang dimaksud dengan fasilitas belajar berupa kelengkapaan belajar yang harus dimiliki oleh sekolah yang dapat memudahkan dan melancarkan pelaksanaan pembelajaran (Fauzi, 2012).

\section{Guru}

Faktor guru, faktor ini mendukung penyebab kesulitan belajar siswa, hal ini terlihat dari data angket siswa bahwa sebagian siswa berpendapat bahwa gurunya kurang demokratis dalam mengajar, dan guru bialogi berpenampilan menarik, dengan demikian apabila guru kurang demokratis dalam mengajar otomatis siswanya akan malas mengikuti pelajaran yang diajarkan oleh guru, karena ia berpendapat guru nya pilih kasih dan percuma saya belajar rajin kalau tidak di hargai.

Guru akan menjadi faktor kesulitan belajar apabila Guru tidak mampu, baik dalam pengambilan metode yang digunakan atau dalam mata pelajaran yang dipegangnya. Selain itu hubungan guru dengan siswa yang kurang baik. Hal ini bermula pada sifat dan sikap guru yang kurang disukai oleh siswanya (Fauzi, 2012).

\section{Materi pembelajaran}

Faktor materi pembelajaran, faktor ini mendukung penyebab kesulitan belajar pada siswa, hal ini dapat kita lihat dari data angket yang diperoleh siswa kurang mengerti istilah-istilah yang digunakan dalam materi sistem pencernaan makanan, sebagian siswa sangat sulit mengingat istilah-istilah yang digunakan dalam materi sistem pencernaan makanan, siswa kesulitan dalm mengingat gangguan yang terjadi dalam sistem pencernaan manusia.

\section{Media}

Faktor media, faktor ini mendukung dalam menyebabkan kesulitan belajar siswa pada materi
pISSN : $2338-3003$

elSSN : $2502-3217$

sistem pencernaan makanan, media yang dimaksud disini adalah media massa seperti televisi, bioskop, majalah, HP, dan teman bergaul dalam masyarakat. Dari data angket yang diperoleh siswa dalam sehari bisa menghabiskan waktunya dengan menonton televisi mulai dari 4-5 jam/hari, sebagian siswa juga menghabiskan waktunya dengan bermain HP senyak 4-5 jam perhari, waktu tersebut merupakan waktu yang cukup lama dipergunakan untuk hal yang kurang bermanfaat dan otomatis berpengaruh terhadap waktu belajar siswa

\section{Metode Pembelajaran}

Faktor metode pembelajaran, faktor ini mendukung dalam menyebabkan kesulitan belajar siswa pada materi sistem pencernaan makanan, hal ini dapat dilihat dari data angket siswa yang sebagian besar siswa berpendapat bahwa gurunya kurang memvariasikan metode pembelajaran yang digunakannya dan terkadang guru hanya menggunakan metode ceramah saja, dan siswa kesulitan menarik kesimpulan di akhir pembelajaran pada materi sistem pencernaan makanan.

\section{KESIMPULAN}

Hasil penelitian menunjukkan bahwa siswa kelas XI MIA SMA Negeri 16 Medan memiliki kesulitan belajar dalam mempelajari materi pokok sistem ekskresi manusia paling tinggi yaitu pada indikator 3 yaitu mendeskripsikan struktur dan fungsi kulit sebagai alat ekskresi (64\%) dan faktor yang menyebabkan kesulitan belajar siswa yang paling tinggi presentase yaitu faktor motivasi $(80,72 \%)$

\section{DAFTAR PUSTAKA}

Ahmadi, A., (2009), Psikologi Umum, Rineka Cipta, Jakarta.

Arikunto, S., (2013), Dasar-Dasar Evaluasi Pendidikan, Bumi Aksara, Jakarta.

Djamarah, Syaiful, B., (2011). Psikologi Belajar. Rineka Cipta : Jakarta. 
JURNAL PELITA PENDIDIKAN VOL. 5 NO. 4

Rapikah, U., Harsono, T., Darussalim, Herawati, Masdiana

Halaman : 371 - 380

Abante, R., Almendral, Manansala, Manibo, (2014), Learning Styles and Factors Affecting the Learning of General Engineering Students, International Journal of Academic Research in Progressive Education and Development, Vol. 3, No. 1 : 2226-6348.

Fauzi, Danang, Tri, (2015), Faktor-Faktor Kesulitan Belajar Matematika Kelas IV MI YAPPI Mulusan Paliyan Gunung Kidul, Skripsi.

Ismail, (2016), Diagnosis Kesulitan Belajar Siswa Dalam Pembelajaran Aktif Di Sekolah, Jurnal Edukasi Vol 2, Nomor 1, 2460-4917.

Lestari, S, E., (2006), Buku Untuk SMA Kelas XI, Departemen Pendidikan Nasional, Jakarta.

Ma'rifah, S., (2013), Efektifitas Penerapan Metode Talking Stick Dengan Media Power Point Terhadap Hasil Belajar Dan Motivasi Belajar Siswa Pada Materi Pokok Sistem Pencernaan Makana Pada Manusia, Skripsi, Fakultas Sains dan Teknologi Universitas Islam Negeri Sunan Kalijaga, Yogyakarta.

Nurhayati, N., (2014), Bank Soal Biologi Untuk SMA, Penerbit Yrama Widia, Bandung.

Octavia, F, R., (2015), Analisis Kemampuan Siswa Kelas $X$ Pada Ranah Kognitif, Afektif Dan Psikomotorik, Jurnal Fisika dan Pendidikan Fisika Vol 1, No 2: 2443-2911.

Pratiwi, Dkk., (2001), Biologi Untuk SMA Kelas XI, Erlangga, Jakarta.

Setya, A., (2009), Faktor-Faktor Yang Mempengaruhi Kesulitan Belajar Mata Pelajaran Teknologi Informasi Dan Komunikasi Siswa Kelas VII Semester 1 SMP Islam Hidayatullah Semarang, Skripsi. FMIPA Univesritas Negeri Semarang, Semarang.

Siregar, H., (2012), Analisis Kesulitan Belajar Siswa Pada Mata Pelajaran Biologi Di Kelas X Semester I SMA N 1 Dolok Masihul Tahun Ajaran 2011/2012, Skripsi. FMIPA Universitas Negeri Medan, Medan.

Slameto, (2010), Belajar dan Faktor-Faktor yang Mempengaruhinya, Penerbit Rineka Cipta,Jakarta.

Soewolo, (2003), Fisiologi Manusia, FMIPA Universitas Negeri Malang, Malang.
pISSN : 2338 - 3003

elSSN : $2502-3217$

Sudijono, A., (2009), Pengantar Evaluasi Pendidikan, Raja Grapindo, Jakarta.

Sudjana, (2012), Metode Statistik, Tarsito, Bandung.

Surmiyati, Patmi, S., Kristayulia, (2010), Analisis Kemampuan Kognitif Dan Kemampuan Afektif Terhadap Kemampuan Psikomotor Siswa Kelas X Sman 3 Mataram Setelah Penerapan Kurikulum Tingkat Satuan Pendidikan (KTSP), Jurnal.

Suryani, Erma, Y., (2010), Kesulitan Belajar, Magistra 0215 -9511.

Suryosuroto, B., (2002), Proses Belajar Mengajar di Sekolah, Rineka Cipta, Jakarta.

Syah, M., (2011), Psikologi Pendidikan dengan Pendekatan Baru. Remaja Rosdayakarya, Bandung.

Winanda, Sri, (2015), Analisis Kognitif dan Kesulitan Belajar Siswa pada Materi Pokok Sistem Saraf di Kelas XI SMA Negeri 3 Sibolga Tahun Pembelajaran 2015/2016, Skripsi. FMIPA Universitas Negeri Medan, Medan. 